\title{
Sickle Cell Anaemia: Errors in Haemoglobin Genotyping: Impact on Parents of Children Attending Two Hospitals in South East Nigeria
}

\author{
J. M. Chinawa'1,2, P. C. Manyike ${ }^{3,4}$, A. E. Aronu ${ }^{1,2}$, H. A. Obu1,2, A. T. Chinawa ${ }^{5}$ \\ ${ }^{1}$ College of Medicine, Department of Pediatrics, University of Nigeria, Nsukka, Nigeria \\ ${ }^{2}$ University of Nigeria Teaching Hospital (UNTH), Ituku, Nigeria \\ ${ }^{3}$ College of Medicine, Ebonyi State University, Abakalki, Nigeria \\ ${ }^{4}$ Department of Pediatrics, Federal Teaching Hospital, Abakiliki (FETHA), Abakiliki, Nigeria \\ ${ }^{5}$ College of Medicine, Department of Community Medicine, Enugu State University of Science and Technology, \\ Enugu, Nigeria \\ Email: maduabuchichinawa@yahoo.com
}

Received 31 December 2014; accepted 28 January 2015; published 30 January 2015

Academic Editor: Carl Friedrich Classen, University Children's Hospital Rostock, Germany

Copyright (C) 2015 by authors and Scientific Research Publishing Inc.

This work is licensed under the Creative Commons Attribution International License (CC BY).

http://creativecommons.org/licenses/by/4.0/

(c) (i) Open Access

\section{Abstract}

Objectives: The study is aimed at determining that errors in assigning genotypes to intending couples do exist; and the impact of these errors on parents. Methods: The study was conducted at the children clinics in Enugu and Abakiliki, south east Nigeria. It is a cross-sectional retrospective study in which a review of the records of all the children attending 2 private clinics in Enugu and Abakaliki of Enugu and Ebonyi states respectively, over a 3-year period was done. Results: A total of 6006 children attended the children clinics over the study period. Twenty three (23) of them had sickle cell anaemia. Out of the 23 cases 10 (43.5\%) were males and $13(56.5 \%)$ were females. Male to female ratio was 1:1.3. The commonest features were abdominal and leg pains, involving $20(87 \%)$ and $21(91.3 \%)$ respectively. Among the 23 parents that had their genotypes repeated, 9 males had different genotypes from what they had during courtship or before marriage. The genotypes of all the females that could recall their genotypes before marriage or during courtship were the same after a repeat test. Conclusions: There exist errors in assigning genotypes to parents which at the end made them have children with sickle cell anemia, unwittingly, with serious consequences bordering on strained relationship between the parents with the children bearing the brunt. 


\section{Keywords}

\section{Sickle Cell Anaemia, Children, Errors}

\section{Introduction}

Sickle cell anaemia (SCA) is a genetic haematological disorder characterized by red blood cells that assume an abnormal, rigid, sickle shape [1]. This hereditary disorder contributes the equivalent of $3.4 \%$ mortality among under 5 children worldwide [2].

Sickle cell disorders were originally found in the tropics and subtropics but are now common worldwide due to migration of people from tropical to temperate zones [2]. The prevalence of sickle cell anaemia in Nigeria ranges from $0.4 \%$ - 3\% affecting about 20 per thousand newborns [3].

Episodic attacks of pain are the most common features of sickle cell anaemic crises and are the most frequent reason for hospitalization [4]. Vaso occlusive crises among children with sickle cell anemia present in different forms with different prevalence rates. For instance, hand foot swelling (dactylitis) occurs in about $30 \%$ of children in the first 3 years of life; avascular necrosis of the femoral head affects children over 13 years of age probably due to the hypoxic ischaemic necrosis and occlusion of the vessels that supply neck of femur [5]. The central nervous system infarction could present as cerebrovascular accidents (CVA) in about $4.01 \%$ of sickle cell anaemia patients [6].

Genotyping is the process of determining differences in the genetic make-up of an individual by examining the individual's DNA sequence using biological assays and comparing it to another individual's sequence or a reference sequence [6]. Genotyping error is defined as the proportion of mistyping of called genotypes [7]-[10]. This may occur due to non-specificity of experimental assay, inappropriate allele calling, or random assay instability [7]-[10].

Unfortunately, majority of the work on Sickle cell anaemia were carried out in teaching hospitals. Much has not been documented on the topic in a private hospital setting. This study is also aimed at establishing the fact that errors in assigning genotype to intending couples do exist as these parents who thought they had no problems with their genotypes before marriage end up having children with SCA after marriage. However when a repeat genotype was done for the parents, it was different from what was obtained hitherto.

\section{Methods}

\subsection{Study Area and Period}

The study was conducted in two children clinics in Enugu and Abakaliki, south east Nigeria. The clinics which are located in highly dense areas provide only outpatient and inpatient care.

The clinics provide care for children and also handle all cases in general pediatrics. Enugu and Ebonyi States of Nigeria have populations of about 3.3 million and 2.2 million people respectively, according to the national census of 2006 [11].

\subsection{Study Design and Study Procedure}

This is a cross-sectional retrospective study where a review of the records of all children attending the clinics over a 3-year period was undertaken. The folders of these children were retrieved from the clinics' records and examined individually by the investigators. Haemoglobin genotypes of the children were determined by haemoglobin electrophoresis using cellulose acetate at a PH of 8.6 as has been recommended [12]. Cellulose strips measuring $140 \times 120 \mathrm{~mm}$ were soaked in buffer and gently bloated. The strips were placed in an electrophoretic tank and secured at each side by a double layer of whitman filter paper [12].

Haemoglobin solution was applied in a $2 \mathrm{~cm}$-line midway between the centre of the strip and at the cathode. Another haemoglobin solution with a known electrophoretic pattern was similarly applied to another cellulose strip to serve as control. Electrophoresis was carried out for 2 hours at $5 \mathrm{MA}$ and a potential of $220 \mathrm{~V}$ across the strip. Thereafter, the membrane was removed with a pair of forceps and dried for 10 - 30 minutes. The electrophoretic band was then inspected [12].

The parents provided their genotype results before marriage or at the time of courtship. Their genotypes were 
repeated when we found that their children are HBSS genotype after presenting with crisis.

The families were assigned socioeconomic classes using the recommended method (modified) by Oyedeji [13].

\subsection{Data Analysis}

Rates and proportions were calculated with 95\% confidence intervals (CI). Level of significance was set at P < 0.05 .

\section{Results}

A total of 6006 children attended the children clinics over the study period. Twenty three (23) of them had sickle cell anaemia. Out of the 23 cases 10 (43.5\%) were males and 13 (56.5\%) were females. Male to female ratio was 1:1.3. The commonest features were abdominal and leg pains, involving 20 (87\%) and 21 (91.3\%) of the 23 cases respectively with one case of acute osteomyelitis confirmed by clinical findings and X-rays (Table 1 ).

Age group ranged from (one) 1 year to 17 years (Table 2).

Among the 23 parents that had their genotypes repeated, 9 males had a different genotype from what they had during courtship or before marriage. The genotypes of all the females that could recall their genotypes before marriage or during courtship were the same after a repeat test.

About 2 males and 1 female did not know their genotypes before marriage (Table 3). One of the parents had a twin and the twins are of HBSS genotype.

Table 1. Common features of presentation of cases.

\begin{tabular}{ccc}
\hline Symptoms & Number of cases & Percentage (\%) \\
\hline Abdominal pains & 20 & 87 \\
Lower limb pains & 21 & 91.3 \\
Complications & & 4.3 \\
Acute Osteomylities & 1 & \\
\hline
\end{tabular}

Table 2. Percentages distribution of the children by sex and parents' social class.

\begin{tabular}{cc}
\hline Sex of children & Frequency $\mathbf{n}=\mathbf{2 3}$ \\
\hline Female & 13 \\
Male & 10 \\
Total & $\mathbf{2 3}$ \\
Social class of parents & 2 \\
Upper & 2 \\
Middle & 19 \\
Lower & 2 \\
\hline
\end{tabular}

\section{Table 3. Errors on genotyping.}

\begin{tabular}{ccc}
\hline Gender of Parent & Genotype before wedding (n) & Repeated genotype of parents after child was ill \\
\hline Male & AA 23 & AS 9, AA 14 \\
& AS 0 & AS 0 \\
Female & SS 0 & SS 0 \\
& AS 21 & AS 21 \\
\hline
\end{tabular}




\section{Discussion}

Sickle cell disorder affects millions of people worldwide and is particularly common among people of African descent [14]. The commonest presentation among children with sickle cell anemia is vaso-occlusive crisis. This is also in keeping with that of Chinawa et al. [15]. Other studies also corroborated these findings [16] [17].

We noted with interest from this study that majority of children with sickle cell anemia are from middle and low socio economic classes. The reason for this finding could be that children whose parents are from high socio-economic class are well taken care of, well fed and followed up regularly, so hospital visits are reduced to the barest minimum [18].

It is pertinent to note from this study that some parents presented with different genotypes from what they had before marriage. Genotype error has caused a lot of havoc among married couples especially when parents are assigned genotypes of AA and AS with some of their children having recurrent illnesses in their early childhood. These recurrent illnesses are usually mistaken for malaria or enteric fever since no one will ever think of sickle cell crises. In all our cases, the children had been treated either for drug resistant malaria or gastritis for abdominal pains. However, when this fever and leg pains occurred repeatedly, a genotype was ordered, not minding that the known genotypes of the parents can't suggest sickle cell in their children. Surprisingly, the children were all SS. Their parents had their genotypes redone and were all found to be both AS. The reason for these errors in genotyping may not be known, but reasons ranging from suboptimal laboratory conditions at the time of the first analysis, file confusion, lab methodology and mis-reporting of the men have been adduced. However, further analysis of these reasons may be an area for further study.

We noted with interest that the genotypes of the female parents were the same before and after marriage while that of the male parents at courtship were not the same after marriage. Errors in relaying the information on genotype status from the laboratory scientist to the females or possibly denial and/or shame on the females in accepting results could account for the male/female differences.

Errors in assigning genotypes to parents affect both the parents and children in so many ways. This is shown as anger and frustration and at times less love for the wife and even the children by the father. This is exacerbated by the extra money paid on hospital bills of the children with sickle cell anemia. The mother also shows anger and frustration, and gripped by fear of divorce. This could lead to serious family strife with the children bearing the brunt.

Although genotyping errors affect most parents and can cause family schism, it is too often neglected. Errors have various causes other than that mentioned above, but their occurrence and effect can be limited by considering these causes during haemoglobin electrophoresis. Procedures that have been developed for dealing with errors such as linkage studies, forensic analyses and non-invasive genotyping should be applied more broadly to any genetic study [19].

For instance, the recently released Gene Chip Mapping $10 \mathrm{~K}$ array offers the ability to genotype over 10,000 SNPs on a single array [20] [21]. This technology uses an innovative assay that eliminates the need for locusspecific PCR and requires only 250 of ng DNA for each sample [20] [21]. This result suggested a fairly high degree of accuracy. In all the laboratories where the genotypes of the parents were done both before and after marriage, $\mathrm{Hb}$ electrophoresis was used; a more refined high performance liquid chromatography may have reduced these errors. For instance, it is noted that high-performance liquid chromatographic methods which was developed for either screening or confirmation of hemoglobinopathies has relatively high sensitivity or specificity when compared with $\mathrm{Hb}$ electrophoresis [21].

We recommend a protocol for estimating error rates and propose that these measures be systemically reported to attest its reliability. We also recommend incorporation of genotyping in school health program. This will at least clarify the genotypes of the students way before marriage.

\section{Conclusion}

There exist errors assigning genotype to parents which at the end make them have children with sickle cell anemia, unwittingly, with serious consequences bordering on strained relationship between the parents, with the children bearing the brunt.

\section{Limitation}

A study of errors in genotyping in a wider population or in a community would be worthwhile. 


\section{References}

[1] Quirolo, K. and Vichinsky, E. (2004) Haemoglobin Disorders. In: Behrmen, R.E., Kliegman, E.M., Jenson, H.B., Eds., Nelson Text Book of Paediatrics, 17th Edition, Saunders Company, Philadephia, 1623-1634.

[2] Livingstone, F.B. (1975) Abnormal Haemoglobins in Human Populations. Vol. 25, Aldine, Chicago, 1-12.

[3] Araba, A.B. (1976) A Survey of Haematological Variable in 600 Healthy Nigerians. Nigerian Medical Journal, 6, 49-53.

[4] Kambel, M. and Chatravedep, P. (2000) Epidemiology of Sickle Cell Disease in a Rural Hospital of Central India. India J Paediatr, 37, 391-396.

[5] Ebong, WW. (1977) Avascular Necrosis of the femoral Head Associated with Haemoglobinopathy. Trop Geogr Med, 29, 19-23.

[6] Ohene-Frempong, K., Weiner, S.J., Sleeper, L.A., Miller, S.T., Embury, S., Moohr, J.W., kinney, S.T. and Platt, O.S. (1998) Cerebrovascular Accidents in Sickle Cell Disease: Rates and Risk Factors. Blood, 9, 288-294.

[7] Genotyping-Wikipedia, the Free Encyclopedia. http://en.wikipedia.org/wiki/Genotyping

[8] Abecasis, G.R., Cherny, S.S. and Cardon, L.R. (2001) The Impact of Genotyping Error on Family-Based Analysis of Quantitative Traits. European Journal of Human Genetics, 9, 130-134. http://dx.doi.org/10.1038/sj.ejhg.5200594

[9] Abecasis, G.R., Cherny, S.S., Cookson, W.O. and Cardon, L.R. (2002) Merlin- Rapid Analysis of Dense Genetic Maps Using Sparse Gene Flow Trees. Nature Genetics, 30, 97-101. http://dx.doi.org/10.1038/ng786

[10] Akey, J.M., Zhang, K., Xiong, M., Doris, P. and Jin, L. (2001) The Effect That Genpyping Errors Have on the Robiustness of Common Linkage Disequilibrium Measures. The American Journal of Human Genetics, 68, 1447-1456. http://dx.doi.org/10.1086/320607

[11] National Population Commission (2006) Provisional Census Figures. Census News, 31, 14.

[12] Roberts, S., Kenneth, A. and Henry, M. (2005) Measurement of Coagulation Factors. In: Marc, S., Robert, P. and Patrick, C., Eds., Haematology in Clinical Practice, 4th Edition, McGraw-Hill Medical Publishers, London, 329-330.

[13] Oyedeji, G.A. (1985) Socio-Economic and Cultural Background of Hospitalized Children in Ilesha. Nigerian Journal of Paediatrics, 12, 111-117.

[14] Organização Mundial de Saúde (2006) Sickle-Cell Anaemia. 59th World Health Assembly, 11, $26-27$.

[15] Chinawa, J.M., Chukwu, B.F., Ikefuna, A.N. and Emodi, I.J. (2013) Musculoskeletal Complications among Children with Sickle Cell Admitted in University of Nigeria Teaching Hospital Ituku-Ozalla Enugu: A 58 Month Review. Annals of Medical \& Health Science Research, 3, 564-567. http://dx.doi.org/10.4103/2141-9248.122110

[16] What Gender Does Sickle Cell Affect? http://www.answers.com/Q/What gender does Sickle cell affect

[17] Ikefuna, A.N. and Emodi, I.J. (2007) Hospital Admission of Patients with Sickle Cell Anaemia Pattern and Outcome in Enugu Area of Nigeria. Nigerian Journal of Clinical Practice, 10, 24-29.

[18] Okany, C.C. and Akinyanju, O.O. (1993) The Influence of Socio-Economic Status on the Severity of Sickle Cell Disease. African Journal of Medicine and Medical Sciences, 22, 57-60.

[19] Pompanon, F., Bonin, A., Bellemain, E. and Taberlet, P. (2005) Genotyping Errors: Causes, Consequences and Solutions. Nature Reviews Genetics, 6, 847-846. http://dx.doi.org/10.1038/nrg1707

[20] Kennedy, G.C., Matsuzaki, H., Dong, S.L., Liu, W.-M., Huang, J., et al (2003) Large-Scale Genotyping of Complex DNA. Nature Biotechnology, 21, 1233-1237. http://dx.doi.org/10.1038/nbt869

[21] Matsuzaki, H., Loi, H., Dong, S.L., Tsai, Y.-Y., Fang, J., Law, J., et al. (2005) Parallel Genotyping of over 10,000 SNPs Using a One-Primer Assay on a High-Density Oligonucleotide Array. Genome Research, 14, 414-425. http://dx.doi.org/10.1101/gr.2014904 
Scientific Research Publishing (SCIRP) is one of the largest Open Access journal publishers. It is currently publishing more than 200 open access, online, peer-reviewed journals covering a wide range of academic disciplines. SCIRP serves the worldwide academic communities and contributes to the progress and application of science with its publication.

Other selected journals from SCIRP are listed as below. Submit your manuscript to us via either submit@scirp.org or Online Submission Portal.
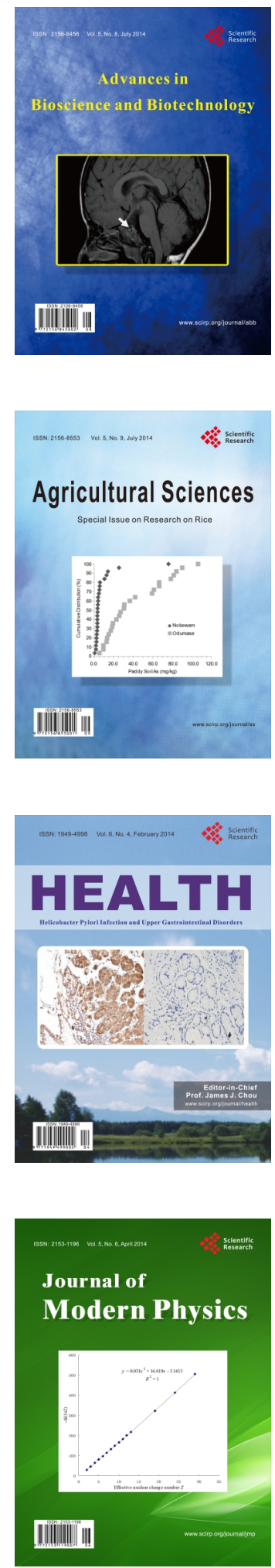
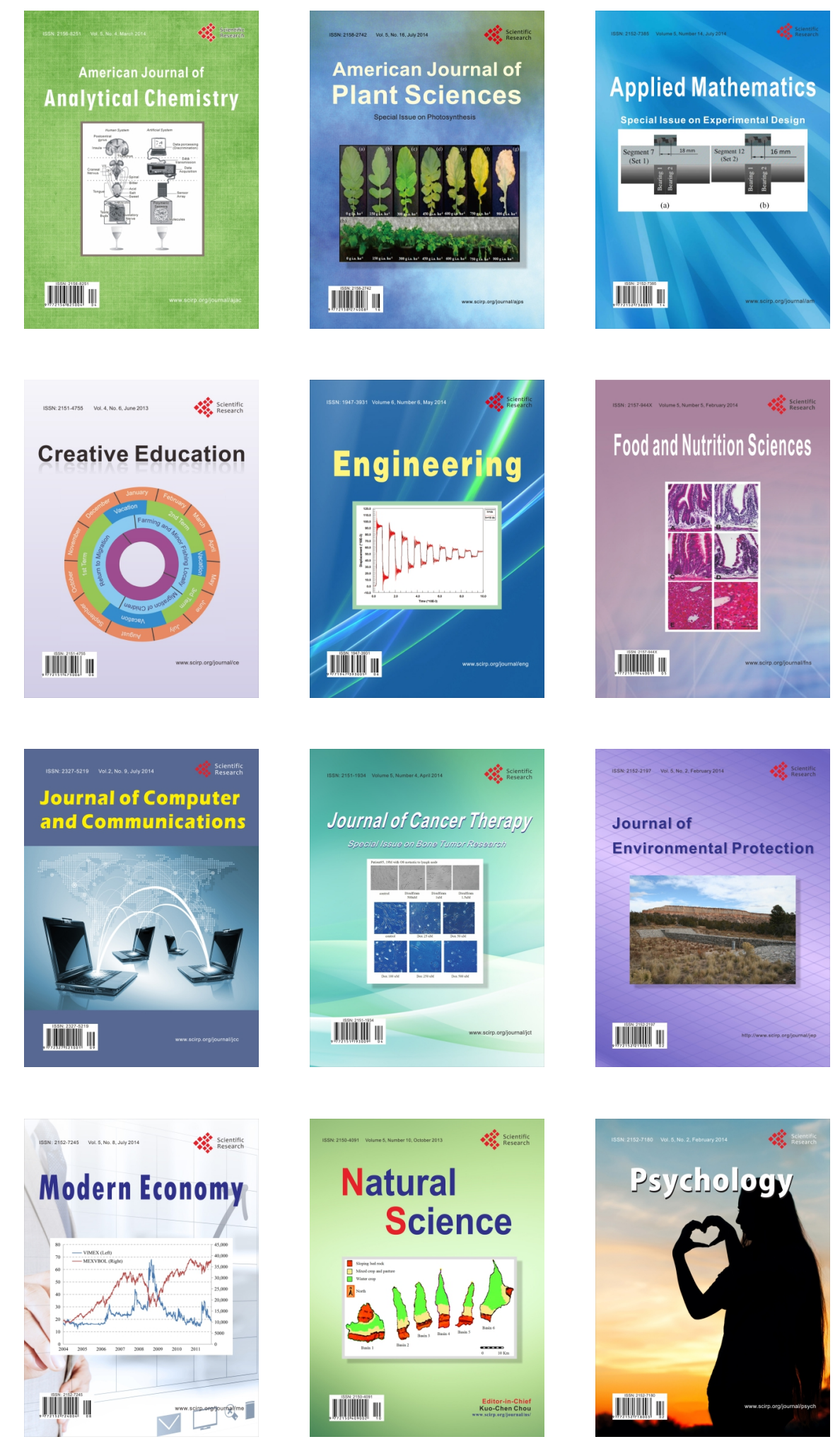